\title{
Biostratigraphy and Mass Extinction Pattern across the Cretaceous/Paleogene Boundary, Northern Alborz, Iran
}

\author{
Masoud Asgharian Rostami ${ }^{1 *}$, Mohammad Vahidinia ${ }^{1}$, Ebrahim Ghasemi-Nejad $^{2}$, Abbas Sadeghi $^{3}$ \\ ${ }^{1}$ Department of Geology, Faculty of Science, Ferdowsi University of Mashhad, Mashhad, Iran \\ ${ }^{2}$ Department of Geology, Faculty of Science, University of Tehran, Tehran, Iran \\ ${ }^{3}$ Department of Geology, Faculty of Science, Shahid Beheshti University, Tehran, Iran \\ Email: *masoud.rostami@hotmail.com
}

Received November 12, 2012; revised December 13, 2012; accepted January 9, 2013

\begin{abstract}
High resolution sampling across the Cretaceous/Paleogene boundary $(\mathrm{K} / \mathrm{Pg})$ at the Galanderud section in northern Iran provides the most expanded and continuous section for us to consider biostratigraphy and the mass extinction pattern of Cretaceous planktic foraminifera. Based on planktic foraminifera, four biozones and five sub-biozones have been identified across the K/Pg boundary. These biozones include the Abathomphalus mayaroensis Biozone (Plummerita hantkeninoides subbiozone), the Guembelitria cretacea Biozone (including two sub-biozones: the Hedbergella holmdelensis and the Parvularugoglobigerina longiapertura), the Parvularugoglobigerina eugubina Biozone (including two subbiozones: the Parvularugoglobigerina Sabina and the Eoglobigerina simplicissima) and finely the Parasubbotina pseudobulloides Biozone. Planktic foraminiferal extinction occurred over a brief period, with $3 \%$ of the species disappearing in the late Maastrichtian, and $72 \%$ of the species becaming extinct at the K/Pg boundary. About $25 \%$ of the species are survived into the early Danian. Extinction of $73 \%$ of the species at the $\mathrm{K} / \mathrm{Pg}$ boundary is very compatible with the effect of a large asteroid impact.
\end{abstract}

Keywords: Biostratigraphy; Mass Extinction Pattern; Cretaceous/Paleogene Boundary; Northern Alborz; Iran

\section{Introduction}

The Cretaceous-Paleogene boundary $(\mathrm{K} / \mathrm{Pg})$ is one of the major crises in the history of life on Earth. Planktonic foraminifera suffered the most dramatic extinctions among marine organisms across the Cretaceous-Paleogene boundary. The proposed causes of this mass extinction are widely considered as a combination of degassing of the Deccan Traps and a bolide impact in Chicxulub, Mexico [1]. Alvarez and his colleagues [2] suggested the bolide impact theory as the cause for the mass extinctions at Cretaceous-Paleogene boundary. This meteorite impact is evidenced by anomalous abundance of Ir, microtektites, shocked quartz and Ni-rich spinels in K/Pg boundary deposits. Also, Courtillot [3] and Keller et al., 2011 pointing out the key role of volcanic eruptions in mass extinction at the end of the Cretaceous. The planktonic foraminifera mass extinction at the K-Pg boundary event has been pointed out by many specialists [4-6]. The aim of this paper is to determine the biostratigraphy and model the extinction pattern of planktonic foraminiferal species in the Galanderud section.

*Corresponding author.

\section{Location and Lithology}

The Alborz Mountain system of northern Iran, extends in a sinuous manner for about $2000 \mathrm{~km}$ from the Lesser Caucasus of Armenia and Azerbaijan Republics of the former Soviet Union to the Paropamisus Mountains of northern Afghanistan in the northeastern corner of Iran east [7].

The section that was sampled is located next to a limestone mine, about $25 \mathrm{~km}$ south of the city of Royan and in the southwest corner of Noor province. An exposure of $7 \mathrm{~m}$ spanning the K/Pg boundary was sampled at 5 $10 \mathrm{~cm}$ intervals, except for the boundary clay where samples were taken at $2 \mathrm{~cm}$ intervals. This study includes about $2 \mathrm{~m}$ of Maastrichtian and $5 \mathrm{~m}$ of Danian sediment. Sediments of the upper most Maastrichtian consist of brown to dark brown marls, The K/Pg transition is marked by a lithological change from brown marl at end of Maastrichtian to a clay layer preceding a chalk layer at base of Danian.

\section{Materials and Methods}

Samples were collected every 5 to $10 \mathrm{~cm}$ and every $2 \mathrm{~cm}$ at the critical K/Pg boundary interval. A total of 54 samples 
were analyzed for study. The samples were processed for foraminiferal analysis by standard micropaleontological techniques. They were disaggregated in tap water and washed through a $120 \mu \mathrm{m}$ and $53 \mu \mathrm{m}$ sieve and dried at $50^{\circ} \mathrm{C}$. Preservation of the planktic Foraminifera were good to very good. In order to prevent the Signor and Lipps effect, a blind test at $\mathrm{K} / \mathrm{Pg}$ boundary was used to precisely examine samples for rare species in several sieves [8].

\section{Biostratigraphy}

The Maastrichtian and Danian foraminiferal biozonation used in this paper is based upon studies conducted in middle and lower latitudes. The biozonation of Keller and colleagues [9] and Arenillas and colleagues [10,11] is used for this study with some changes (Figures 1 and 2). We have identified a high-resolution planktic foraminiferal zonation and have described four biozones and five subbiozones across the $\mathrm{K} / \mathrm{Pg}$ boundary in this section. These biozones include: the Abathomphalus mayaroensis Biozone (Plummerita hantkeninoides subbiozone), the Guembelitria cretacea Biozone (including two sub-biozones: the Hedbergella holmdelensis and the Parvularugoglobigerina longiapertura), the Parvularugoglobigerina eugubina Biozone (including two subbiozones: (the Parvularugoglobigerina Sabina and the Eoglobigerina simplicissima) and the Parasubbotina pseudobulloides Biozone.

\subsection{Abathomphalus mayaroensis Zone}

This zone initially introduced by Bronnimann [12] was defined by great diversity of the nominate taxon. This species is rare or absent in shallow water and at high latitudes appeared in the Campanian, but disappears prior to the K/Pg boundary [8].

Based on Keller [9] the A. mayaroensis zone is subdivided into four subzones in stratigraphic order: the $R a$ cemiguembelina fructicosa, the Pseudoguembelina hariaensis, the P. palpebra and the Plummerita hantkeninoides subzones. Also, Keller (1995) initially proposed the Plummerita hantkeninoides Zone for the uppermost Maastrichtian at El Kef, Tunisia and Agost, Spain. Keller definded this subzone as the total range of nominate taxon to determine the uppermost Maastrichtian. At the current section, $P$. hantkeninoides spans the top $2 \mathrm{~m}$ of the Maastrichtian.

\subsection{Guembelitria cretacea Biozone}

This biozone was first defined by Smit 1982 [13]. He introduced the Guembelitria cretacea Zone as the interval between the last occurrence of Cretaceous species at the Cretaceous-Paleogene boundary and the first occurrence of Parvularugoglobigerina eugubina Arenillas et

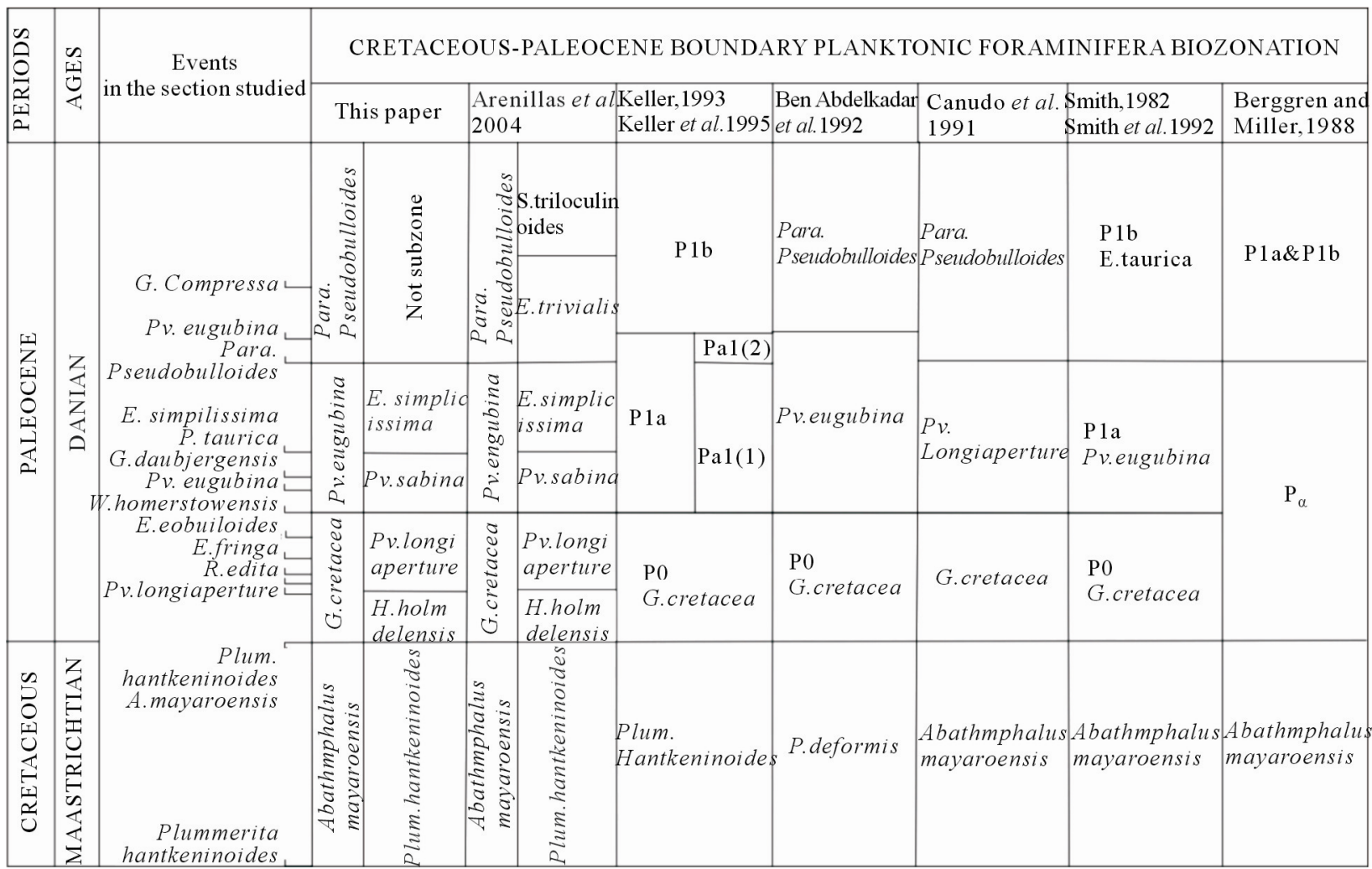

Figure 1. Correlation between the upper Maastrichtian and lower Danian planktic foraminiferal biozonations. 


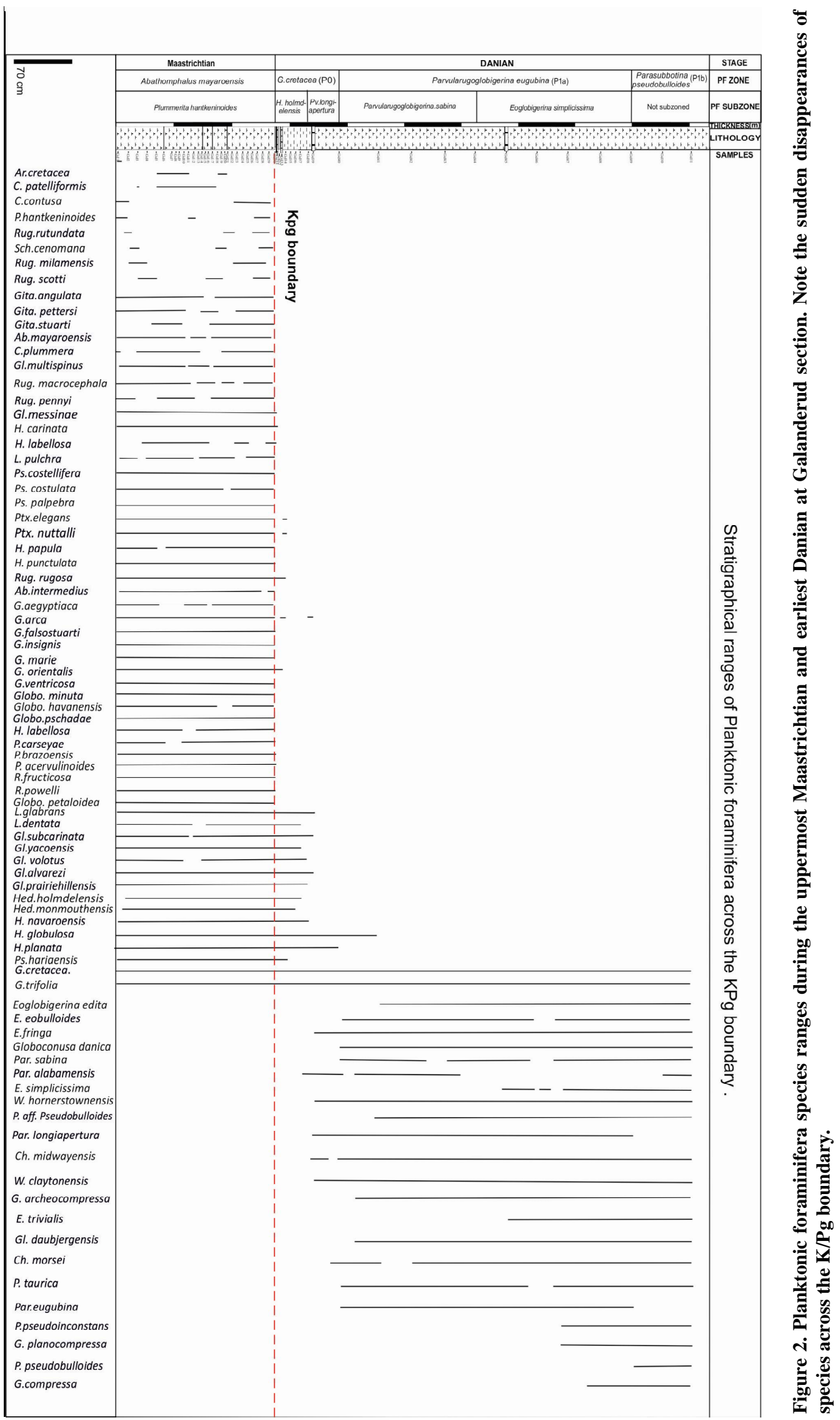


al., 2004 and Parvularugoglobigerina extensa [14]. The Zone is subdivided into two Sub-biozones that include: the Hedbergella holmdelensis and the Parvularugoglobigerina longiapertura Arenillas et al., 2004. The Hedbergella holmdelensis is defined by last occurrence of Cretaceous planktonic foraminifera specially the Globotruncanids, Abathomphalus and Plummerita, to the first occurrence of Parvularugoglobigerina longiapertura. It is equivalent to the P0 Zone of $[13,15]$. The second sub-biozone in the Guembelitria cretacea was defined by first occurrences of Pv. longiapertura and Pv. Eugubina [14]. In the Galanderud section, the Guembelitria cretacea Zone is characterized by high relative abundance of Guembelitria spp. It is $\sim 60 \mathrm{~cm}$ thick.

\subsection{Parvularugoglobigerina eugubina Biozone}

Luterbacher and PremoliSilva (1964) firstly introduced this biozone and it was defined as total range of the nominate taxon. This biozone was divided in two Subzones by Arenillas et al., (2004) that include of Parvularugoglobigerina sabina Subzone, which is the interval ranging from the first occurence of Parvularugoglobigerina eugubina to the first occurence of Eoglobigerina simplicissima; and Eoglobigerina simplicissima Subzone, which is the interval between the first occurence of the nominal taxon and the first occurence of Parasubbotina pseudobulloides.

The first subzone is $\sim 170 \mathrm{~cm}$ thick and the second subzone is $\sim 190 \mathrm{~cm}$ thick.

\subsection{Parasubbotina pseudobulloides Zone}

This zone was initially described by [16]. Arenillas (2004) subdivided the Ps. pseudobulloides Zone into the Eoglobigerina trivialis and $S$. triloculinoides Subzones.

The Eoglobigerina trivialis Subzone includes the bio- stratigraphical interval from the first occurence of Parasubbotina pseudobulloides to first occurence of Subbotina triloculinoides; and the Subbotina triloculinoides Subzone, which is the interval from the first occurence of the S. triloculinoides to the first occurence of Globanomalina compressa. In this section, we could not determine a subzone.

This zone is $\sim 70 \mathrm{~cm}$ thick.

\section{The Mass Extinction Pattern}

Smit 1982 indicated that dominated species of the upper Maastrichtian planktic foraminifera have been recorded in the lower most Danian all are considered to be reworked, except for one species Guembelitria cretacea. Olsson and colleagues (1999) considered Hedbergella holmdelensis, H. monmouthensis and G. cretacea, to be survivors into the lower Danian. Based on these papers, this extinction was a catastrophic mass extinction and resulting from an exterrestrial impact. On the other hand, Gerta Keller and colleagues (1989) presented different data. At these data, they showed gradual pattern across the boundary and they indicate Cretaceous species survive many thousands in Paleocene.

In order to describe the mass extinction pattern the Galanderud section was chosen. Species ranges and extinction patterns are illustrated in across the K/Pg transition, at Galanderud section in (Figures 2 and 3). Based on detail study, we identified 61 Cretaceous species. Based on our data gain following data:

The upper Maastrichtian, planktonic foraminifera are dominated by small biserial species (heterohelicidsand and pseudguembelinids), triserial species and small morphology trochospiral (hedbergellids) are rare in this section. Also, globigerinelloid and globotruncanellid species are also common. Rugoso trochospiral species, complex biserial and multiserial (rugoglobigerinids, pseudotextularids

\begin{tabular}{|c|c|c|c|c|c|c|c|c|c|c|}
\hline Sections an & \begin{tabular}{|l|}
$d$ \\
Keller 1988 \\
$($ EI Kef)
\end{tabular} & $\begin{array}{l}\text { Keller et al } \\
1995 \\
\text { (EI Lef) }\end{array}$ & $\mid \begin{array}{c}\text { Molina et al } \\
1998 \\
\text { (Agost) }\end{array}$ & $\begin{array}{l}\text { Arz et al } \\
1999 \\
\text { (Zumaya) }\end{array}$ & $\begin{array}{c}\text { Arz et al } \\
2000 \\
\text { (Caravaca) }\end{array}$ & $\begin{array}{c}\text { Arenillas et al } \\
2000 \mathrm{a} \\
\text { (Ain settara) }\end{array}$ & $\mid \begin{array}{c}\text { Zaghbib-Turki } \\
\text { et al } 2000 \\
\text { (Elles) }\end{array}$ & $\begin{array}{c}\text { Luciani } \\
2002 \\
\text { (Ain settara) }\end{array}$ & $\begin{array}{l}\text { Gallala } \\
\text { etal } \\
2009 \\
\text { (Bidart) }\end{array}$ & $\begin{array}{r}\text { This section } \\
\text { (Galanderud) }\end{array}$ \\
\hline $\begin{array}{c}\text { Danian } \\
\text { Extinct percen }\end{array}$ & $10(18 \%)$ & $24(19 \%)$ & $16(24 \%)$ & $15(24 \%)$ & $17(25 \%)$ & $18(28 \%)$ & $13(23 \%)$ & $33(57 \%)$ & $4(5.5 \%)$ & $16(26.22 \%)$ \\
\hline $\begin{array}{c}\mathrm{Kpg} \\
\text { Extinct percent }\end{array}$ & $31(58 \%)$ & $7(12 \%)$ & $47(70 \%)$ & $44(71 \%)$ & $49(71 \%)$ & $44(65 \%)$ & $36(63 \%)$ & $13(22 \%)$ & $53(73 \%)$ & $43(70.49 \%$ \\
\hline $\begin{array}{l}\text { Maastrichtian } \\
\text { Extinct percen }\end{array}$ & $12(24 \%)$ & $24(69 \%)$ & $4(6 \%)$ & $3(5 \%)$ & $3(4 \%)$ & $5(7 \%)$ & $8(14 \%)$ & $12(21 \%)$ & $1(1.38 \%)$ & $2(3.27 \%)$ \\
\hline
\end{tabular}

Figure 3. Comparative number and percent of extinct species across the K/Pg boundary and the Cretaceous survivors at the lower Danian interval. 
planoglobulinds and racemiguembelinids) are common.

At the K/Pg boundary, many Cretaceous species suddenly disappear, and only some genera such as Guembelitria, Heterohelix, Globigerinelloides and Hedbergella are common in the clay layer. Based on this study, A. cretacea and Contusotruncana patelliformis (3.27\%) are the only species that disappeared between $2 \mathrm{~m}$ below and the K/Pg boundary, 44 species (72.13\%) became extinct at the K/Pg boundary (Plate 1). The remaining 15 species (about 24.59\%) represent the Cretaceous survivors in the Early Danian sediments, but disappear by $1 \mathrm{~m}$ above the K/Pg boundary in Zones P0 (Plate 1). This pattern supports the sudden catastrophic pattern of species extinctions across the K/Pg boundary elsewhere.

\section{Comparison with Other Section}

There is still the debate regarding the planktic foraminiferal extinction model at the K/Pg boundary. Differences are the result of various selection the methodologies, differences in obtaining the data, and diverse interpretations of the data (Figure 3 ).

The mass extinction pattern at the $\mathrm{K} / \mathrm{Pg}$ boundary of the Galanderud section indicates that (44: 72\%) species became extinct. This extinction at K/Pg boundary is similar to many sections around the world. For example: In Spanish sections (Agost: 46 extinct species (70\%), at Caravaca: 46 extinct species (71\%)) [17].

And in Tunisian sections (El Kef: 46 extinct species

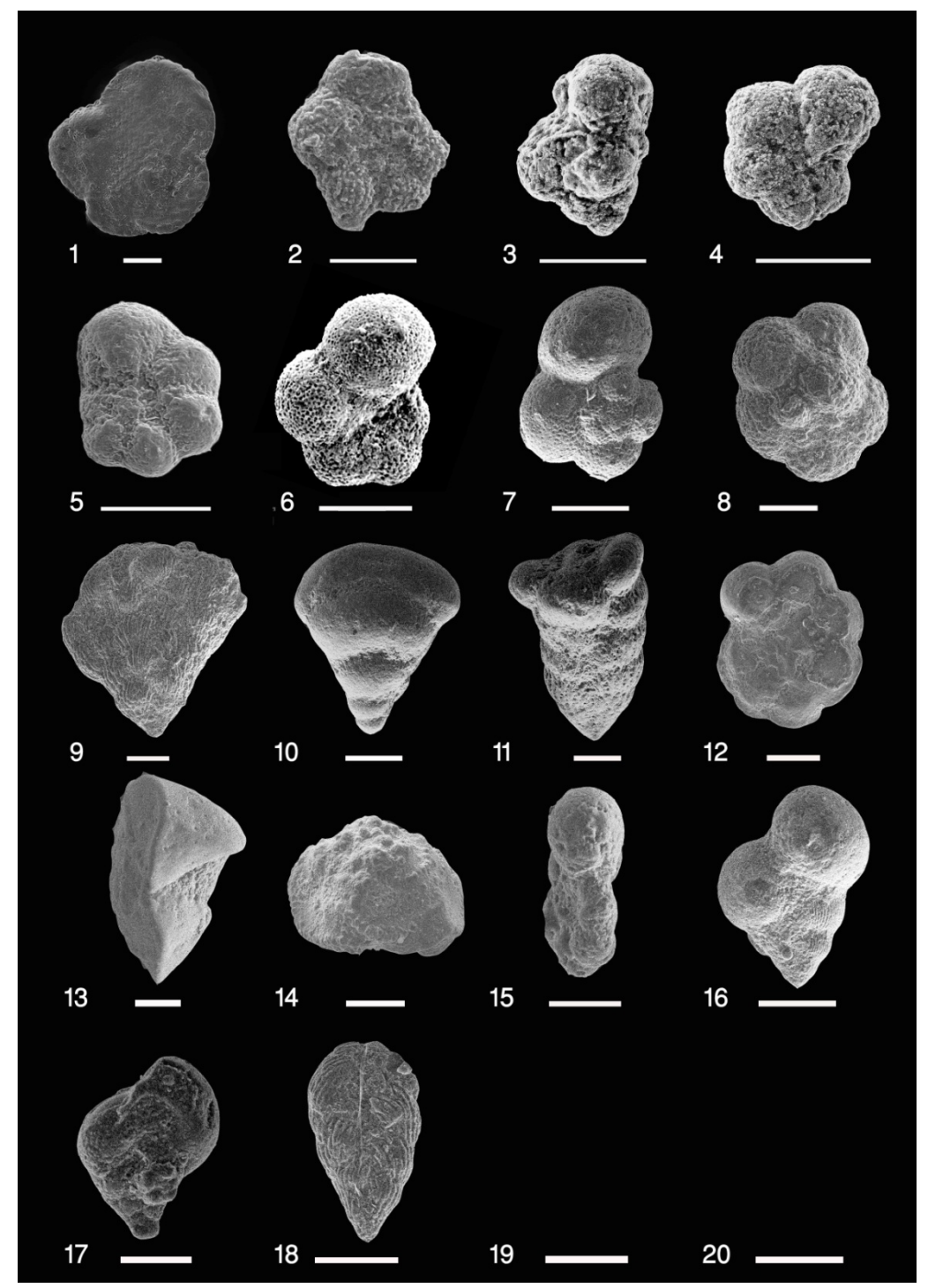

Plate 1: Scalebar = 50 micron; 1. Abathomaphalus mayaroensis; 2. Plummerita hantkeninoides; 3. Guembilitria sp.; 4. Parvularugoglobigerina eugubina; 5. Parvularugoglobigerina longiapertura; 6. Eoglobigerina simpliccicima; 7. Parasubbotina pseudobulloides; 8. Rugoglobigerina rugosa; 9. Planoglobulina sp.; 10. Pseudotextularia nuttalli; 11. Racemiguembelina powelli; 12. Globotruncana arca; 13. Globotruncanita stuartiformis; 14. Contusotruncana. spp.; 15. Globigerinelloides sp.; 16. Heterohelix globulosa; 17. Laeviheterohelix dentata; 18. Pseudoguembelina costulata. 
(58\%), at Elles: 36 or 45 extinct species (37\%), species and at Aïn Settara: 44 extinct species $(65 \%)[10,18]$ and in a French section (Bidart 53 species (73\%) became extinct [19].

\section{Conclusion}

Planktic foraminifera were very abundant and diversified during the late Cretaceous at the Galanderud section. Based on the planktic foraminifera data four biozones and five sub-biozones have been identified across the K/Pg boundary. Late Maastrichtian planktic foraminifera were much diversified and some species reached a very large size. These assemblages, that constituted about $73 \%$ of the species present, suddenly became extinct at the $\mathrm{K} / \mathrm{Pg}$ boundary. This pattern of catastrophic mass extinction constitutes the largest and most dramatic extinction event in the history of planktic foraminifera. This data from this extinction event are very compatible with the catastrophic effects that might have been caused by the impact of a large extraterrestrial body.

\section{REFERENCES}

[1] G. Keller, P. K. Bhowmick, H. Upaidhyay, A. Dave, A. N. Reddy, B. C. Jaiprakash and T. Adatte, "Deccan Volcanism Linked to the Cretaceous-Tertiary Boundary (KTB) Mass Extinction: New Evidence from ONGC Wells in the Krishna-Godavari Basin,” Journal of the Geological Society of India, Vol. 78, No. 5, 2011, pp. 399-428.

[2] L. W. Alvarez, W. Alvarez, F. Asaro and H. V. Michel, "Extraterrestrial Cause for the Cretaceous-Tertiary Extinction,” Science, Vol. 208, No. 4448, 1980, pp. 11951108. doi:10.1126/science.208.4448.1095

[3] V. Courtillot, J. Besse, D. Vandamme, R. Montigny, J.-J. Jaeger and H. Cappetta, "Deccan Flood Basalts at the Cretaceous/Tertiary Boundary?” Earth and Planetary Science Letters, Vol. 80, No. 3-4, 1986, pp. 361-374. doi:10.1016/0012-821X(86)90118-4

[4] H. P. Luterbacher and I. Premoli-Silva, "Biostratigrafia del Limite Cretaceo-Terziario nell’Appennino Centrale,” Rivista Italiana di Paleontologia, Vol. 70, No. 1, 1964, pp. 67-117.

[5] E. Molina, I. Arenillas and J. A. Arz, "The Cretaceous/ Tertiary Boundary Mass Extinction in Planktic Foraminifera at Agost, (Spain)," Revue de Micropaléontologie, Vol. 39, No. 3, 1996, pp. 225-243. doi:10.1016/S0035-1598(96)90075-6

[6] E. Molina, L. Alegret, I. Arenillas and J. A. Arz, "The Cretaceous/Paleogene Boundary at the Agost Section Revisited: Paleoenvironmental Reconstruction and Mass Extinction Pattern,” Journal of Iberian Geology, Vol. 31, No. 1, 2005, pp. 135-148.

[7] M. Alavi, "Tectonostratigraphic Synthesis and Structural Style of the Alborz Mountain System in Northern Iran,” Journal of Geodynamics, Vol. 21, No. 1, 1996, pp. 1-33. doi:10.1016/0264-3707(95)00009-7
[8] J. I. Canudo, G. Keller and E. Molina, “Cretaceous/Tertiary Extinction Pattern and Faunal Turnover at Agost and Caravaca, S.E. Spain,” Marine Micropaleontology, Vol. 17, No. 3-4, 1991, pp. 319-341. doi:10.1016/0377-8398(91)90019-3

[9] G. Keller, L. Li and N. Macleod, "The Cretaceous-Tertiary Boundary Stratotype Section at El Kef, Tunisia: How Catastrophic Was the Mass Extinction?” Palaeogeography, Palaeoclimatology, Palaeoecology, Vol. 119, No. 34, 1996, pp. 221-254. doi:10.1016/0031-0182(95)00009-7

[10] I. Arenillas, J. A. Arz, E. Molina and C. Dupuis, "The Cretaceous/Paleogene (K/P) Boundary at Ain Settara, Tunisia: Sudden Catastrophic Mass Extinction in Planktic Foraminifera," The Journal of Foraminiferal Research, Vol. 30, No. 3, 2000, pp. 202-218. doi:10.2113/0300202

[11] I. Arenillas, J. A. Arz and E. Molina, “A New High-Resolution Planktic Foraminiferal Zonation and Subzonation for the Lower Danian,” Lethaia, Vol. 37, No. 1, 2004, pp. 79-95. doi:10.1080/00241160310005097

[12] P. Bronnimann, "Trinidad Paleocene and Lower Eocene Globigerinidae,” Bulletin of American Paleont, Vol. 34 No. 143, 1952, pp. 1-34.

[13] J. Smit, "Extinction and Evolution of Planktonic Foraminifera after a Major Impact at the Cretaceous/Tertiary Boundary," Special Paper-Geological Society of America, Vol. 190, 1982, pp. 359-372.

[14] R. K. Olsson, C. Hemleben, W. A. Berggren and B. T. Huber, "Atlas of Paleocene Planktonic Foraminifera," Smithsonian Contributions to Paleobiology, Vol. 85, No. 85, 1999, pp. 1-252.

[15] W. A. Berggren and P. N. Pearson, “A Revised Tropical to Subtropical Paleogene Planktonic Foraminiferal Zonation," The Journal of Foraminiferal Research, Vol. 35, No. 4, 2005, pp. 279-298. doi:10.2113/35.4.279

[16] G. P. Leonov and V. P. Alimarina, "Problems on the Boundary between the Cretaceous and Paleogene Systems. Moscow," University Geology Faculty Sbornik Trudov, 1962, pp. 29-60.

[17] E. Molina, I. Arenillas and J. A. Arz, "Mass Extinction in Planktic Foraminifera at the Cretaceous/Tertiary Boundary in Subtropical and Temperate Latitudes,” Bulletin de la Societé Géologique de France, Vol. 169, No. 3, 1998, pp. 351-363.

[18] N. Karoui-Yaakoub, D. Zaghbib-Turki and G. Keller, The Cretaceous-Tertiary (K-T) Mass Extinction in Planktic Foraminifera at Elles I and El Melah, Tunisia,” Palaeogeography, Palaeoclimatology, Palaeoecology, Vol. 178, No. 3-4, 2002, pp. 233-255. doi:10.1016/S0031-0182(01)00398-4

[19] N. Gallala, D. Zaghbib-Turki, I. Arenillas, J. A. Arz and E. Molina, "Catastrophic Mass Extinction and Assemblage Evolution in Planktic Foraminifera across the Cretaceous/Paleogene (K/Pg) Boundary at Bidart (SW France),” Marine Micropaleontology, Vol. 72, No. 3-4, 2009, pp. 196-209. doi:10.1016/j.marmicro.2009.05.001 